\title{
Pengaruh Lama Pemberian Fondaparinux terhadap Activated Partial Thromboplastin Time (APTT) pada Pasien Sindroma Koroner Akut
}

\author{
Arina Dery Puspitasari ${ }^{1}$, Suharjono $^{1}$, Yogiarto $^{2}$ \\ ${ }^{1}$ Departemen Farmasi Klinik, Fakultas Farmasi, Universitas Airlangga, Surabaya \\ ${ }^{2}$ Departemen Kardiologi, RSUD Dr. Soetomo, Surabaya
}

*Corresponding author: arinadp_ffua@yahoo.co.id

\begin{abstract}
Background: Fondaparinux $2.5 \mathrm{mg}$ as an anticoagulant therapy in patient with ACS (Acute Coronary Syndrome) in Dr. Soetomo Hospital Surabaya is given for 5 days, while many literatures state that fondaparinux is given for 3 - 7 days. Steady-state levels can be achieved after 3 - 4 days and the anticoagulant effect of fondaparinux can last for 2 - 4 days after discontinued (normal renal function). This study is needed to determine the influence of duration of fondaparinux $2.5 \mathrm{mg}$ subcutan once daily on days 3, 4, and 5 on Activated Partial Thromboplastin Time (APTT). Objective: The aims of this study were to find out if there was difference based on duration administration of fondaparinux in APTT for ACS patients. Methods: The participants of this study were all patients diagnosed with ACS who were given fondaparinux therapy at Dr. Soetomo Surabaya Hospital. The samples were taken by purposive sampling and prospective observational cohort study. Instruments that used in this research are patient's medical record and APTT records. Patients demographic data and APTT values were analyzed descriptively and One Way Anova was used to find the difference between in each group of duration administration in APTT. Results: The use of fondaparinux increase the value of APTT average and reach the target $(25-40$ seconds) in 9 patients for 3 days $(39.39 \pm 8.02$ seconds $), 4$ days $(39.98 \pm 12.15$ seconds), and 5 days $(40.06 \pm 6.21$ seconds). There is no significant difference of the APTT to the duration of fondaparinux $2.5 \mathrm{mg}$ subcutan once daily for 3, 4, and 5 days $(p>0.05)$. Conclusion: The duration administration of fondaparinux do not differ significantly increasing the value of APTT.
\end{abstract}

Keywords: fondaparinux, duration, activated partial thromboplastin time, acute coronary syndrome

\begin{abstract}
Abstrak
Pendahuluan: Fondaparinux 2,5 mg sebagai terapi antikoagulan pada pasien Sindroma Koroner Akut (SKA) di RSUD Dr. Soetomo Surabaya diberikan selama 5 hari, sedangkan pustaka menyebutkan bahwa fondaparinux diberikan selama 3 - 7 hari. Kadar steady-state dapat dicapai setelah 3 - 4 hari dan efek antikoagulan dari fondaparinux dapat bertahan selama 2 - 4 hari setelah terapi dihentikan pada pasien dengan fungsi ginjal normal. Diperlukan penelitian untuk mengetahui pengaruh lama pemberian fondaparinux 2,5 mg subcutan sekali sehari pada hari ke-3, 4, dan 5 terhadap Activated Partial Thromboplastin Time (APTT). Tujuan: Penelitian ini bertujuan untuk mengetahui apakah ada perbedaan pemberian fondaparinux terhadap nilai APTT pada penderita SKA. Metode: Sampel penelitian ini adalah seluruh pasien yang didiagnosis SKA yang diberikan terapi fondaparinux di RSUD Dr. Soetomo Surabaya. Jenis penelitian ini adalah observasional dengan rancang bangun prospektif kohort. Teknik pengambilan sampel dengan purposive sampling. Instrumen yang digunakan adalah rekam medis pasien dan hasil rekam pengukuran nilai APTT. Data demografi pasien dan nilai APTT dianalisis secara deskriptif dan One Way Anova digunakan untuk mengetahui perbedaan antara masing-masing kelompok terhadap lama pemberian fondaparinux terhadap APTT. Hasil: Penggunaan fondaparinux meningkatkan nilai rata-rata APTT dan mencapai target ( 25 - 40 detik) pada 9 orang pasien selama 3 hari $(39,39 \pm 8,02$ detik), 4 hari (39,98 $\pm 12,15$ detik), dan 5 hari (40,06 $\pm 6,21$ detik). Tidak ada perbedaan bermakna antara APTT dengan lama pemberian fondaparinux 2,5 mg subcutan sekali sehari selama 3, 4, dan 5 hari ( $\mathrm{p}>0,05)$. Kesimpulan: Lama pemberian fondaparinux pada hari ke-3, 4, dan 5 tidak berbeda bermakna dalam meningkatkan nilai APTT.
\end{abstract}

Kata kunci: fondaparinux, lama pemberian, activated partial thromboplastin time, sindroma koroner akut 


\section{PENDAHULUAN}

Terapi anti koagulan merupakan salah satu terapi yang digunakan pada pasien Sindroma Koroner Akut (SKA) yang digunakan untuk menghambat aktifitas pembentukan trombin sehingga mengurangi pembentukan trombus. Kelompok terapi anti koagulan diantaranya adalah UFH (UnFractionated Heparin), LMWH (Low Molecular Weight Heparin), penghambat faktor Xa (fondaparinux), penghambat Langsung Trombin dan antagonis Vitamin K (Bassand, 2007). Saat ini penggunaan UFH dan LMWH sudah mulai berkurang, dan terapi antikoagulan beralih pada fondaparinux. UFH memiliki beberapa kerugian, diantaranya memerlukan monitoring yang intensif, resiko trombositopenia, dan peningkatan resiko perdarahan. LMWH memiliki efek antikoagulan yang lebih dapat diprediksi, tidak memerlukan monitoring laboratoris, resiko trombositopenia yang lebih rendah, dan dapat diberikan secara injeksi subkutan, namun penggunaan LMWH jika dibandingkan dengan UFH menyebabkan peningkatan perdarahan intrakranial pada pasien lanjut usia. Selain itu Heparin dan LMWH merupakan turunan Heparin yang diproduksi dari usus halus babi. Hal tersebut menjadi isu yang perlu dihindarkan dalam penggunaan di Indonesia. Berbeda dengan Fondaparinux yang merupakan sintetik dan tidak mengandung unsur babi. Fondaparinux sebagai antikoagulan generasi terbaru memiliki kelebihan yang lain diantaranya bebas dari pengawet, dosis tetap, dan pemberian yang sekali sehari. Hal ini berbeda dengan Heparin yang mengandung pengawet, dosis disesuaikan dengan berat badan dan pemberian dua kali per hari (Organon Sanofi-Synthelabo, 2002). Fondaparinux memiliki profil farmakokinetik yang linier serta intra dan intervariabilitas yang rendah. Hal ini yang membuat fondaparinux dapat diberikan sekali sehari tanpa monitoring (Simoons dkk., 2004).

Simoons dkk. (2004) telah melakukan penelitian untuk menentukan dosis fondaparinux pada pasien SKA dengan membandingkan penggunaan dosis sebesar 2,5; 4; 8; dan $12 \mathrm{mg}$ sekali sehari selama minimal 3 hari dan maksimal 7 hari. Dengan nilai tengah pemberian selama 5 hari. Dari penelitian tersebut diperoleh hasil bahwa fondaparinux dengan dosis $2,5 \mathrm{mg}$ sekali sehari memiliki efektivitas yang sama dengan dosis yang lebih besar $(4 ; 8 ; 12 \mathrm{mg})$, bahkan dengan efek samping yang lebih kecil, sehingga pada SKA direkomendasikan dosis $2,5 \mathrm{mg}$ (Bassand, 2007). Berdasarkan Guideline American College of Cardiology/American Heart Association (ACC/AHA) tahun 2007 level of evidence fondaparinux berkategori 1B baik untuk terapi invasive pada SKA maupun untuk terapi konservatif (Anderson dkk., 2007). Berdasarkan penelitian Smogorzewska dkk. (2006) menyampaikan bahwa fondaparinux dapat memperpanjang APTT (Activated Partial Thromboplastin Time) pada orang sehat, yakni 3,8 detik lebih panjang dengan kadar fondaparinux dalam darah sebesar $0,4 \mu \mathrm{g} / \mathrm{mL}$ pada dosis $2,5 \mathrm{mg}$. Dari hasil penelitian tersebut dapat disimpulkan bahwa monitoring terapi fondaparinux dapat dilakukan dengan mengukur nilai APTT dalam darah. Dengan target terapi berupa pemanjangan APTT sampai 1,5 - 2 kali dari nilai APTT normal sebagai kontrol.

Dengan beberapa pertimbangan diatas maka terpilih fondaparinux 2,5 $\mathrm{mg}$ sebagai terapi antikoagulan pada penderita SKA di RSUD Dr Soetomo dengan lama pemberian 5 hari. Sedangkan Simoons dkk. (2004) telah melakukan penelitian penggunaan fondaparinux pada penderita SKA untuk menentukan dosis, dengan pemberian minimal 3 hari sampai 7 hari. Namun, dengan tetap mempertimbangkan faktor lain seperti efek samping fondaparinux, interaksi obat, kadar tunak yang dapat dicapai setelah $3-4$ hari, efek bertahan $2-4$ hari setelah fondaparinux dihentikan, biaya yang harus dibayar, lama pengobatan, pemanjangan kadar APTT yang diharapkan, maka perlu dikaji pemberian fondaparinux selama 5 hari tersebut dimana pemberian selama 3 hari oleh Simoons dkk. (2004) dianggap telah memberikan efek antikoagulan yang dianggap baik. Berdasarkan hal diatas kami melakukan penelitian ini untuk mempelajari perbedaan pada lama pemberian fondaparinux 2,5 $\mathrm{mg}$ sekali sehari secara subkutan selama 3, 4, dan 5 hari terhadap nilai APTT.

\section{BAHAN DAN METODE}

Jenis penelitian ini adalah bersifat observasional analitik dengan rancang bangun prospektif kohort. Teknik pengambilan sampel dalam penelitian ini dilakukan tanpa acak (non probability sampling) tipe purposive sampling (pengambilan sampel berdasarkan pertimbangan). Penelitian ini telah lulus Ethical Clearance di RSUD Dr. Soetomo dengan nomor 152/Panke.KKE/VII/2011 pada tanggal 29 Juli 2011.

\section{Sampel}

Sampel penelitian ini adalah seluruh pasien yang sudah melalui anamnesis, pemeriksaan fisik-laboratorik dan didiagnosis Sindroma Koroner Akut (NSTEMI/UA) yang diberikan terapi antikoagulan fondaparinux di RSUD Dr. Soetomo Surabaya pada bulan Agustus 2011 - Desember 2011. Jumlah sampel 
yang diteliti direncanakan sebesar 30 sampel, berdasarkan Dalil Limit Pusat (Central Limit Theorem) yang beranggapan mempunyai sifat distribusi normal (Budiarto, 2001). Selanjutnya pasien dipilih sesuai kriteria inklusi dan eksklusi. Kriteria inklusi penelitian adalah 1) pasien dengan diagnosa SKA Tanpa peningkatan ST (NSTEMI) dan Angina tak stabil; 2) pasien diindikasikan mendapat terapi fondaparinux selama 5 hari; 3) pasien menyetujui informed consent. Sedangkan kriteria eksklusi adalah pasien kontraindikasi dengan terapi antikoagulan (memiliki kecenderungan perdarahan); pasien dengan jumlah platelet < 100.000/ $\mathrm{mm}^{3}$; pasien dengan $\mathrm{ClCr}<$ $30 \mathrm{~mL} /$ menit; pasien dengan berat badan < $50 \mathrm{Kg}$; pasien berusia $\geq 75$ tahun. Kriteria drop out adalah pasien SKA yang mengalami reaksi hipersensitifitas terhadap pemberian fondaparinux selama periode penelitian; pasien SKA yang meninggal selama periode penelitian; pasien SKA yang mengalami perdarahan mayor sebelum masa terapi 3 hari; pasien SKA yang tidak mendapat terapi fondaparinux sekali sehari 2,5 mg secara subkutan selama 5 hari; pasien SKA yang mengundurkan diri dari penelitian. Selanjutnya, pihak keluarga pasien akan diberikan penjelasan dan diminta kesediaan agar pasien dapat terlibat dalam penelitian, kemudian diminta mengisi informed consent.

\section{Bahan}

Sampel darah pasien diambil sebanyak $2 \mathrm{cc}$, dimasukkan kedalam tabung yang diberi Natrium sitrat sebanyak 1,9 $\mu$ L. Sampel darah ke-0, diambil sebelum diberikan terapi fondaparinux, hasilnya digunakan sebagai nilai awal. Sampel darah hari ke-3, ke-4, dan ke-5 diambil saat 2 jam setelah fondaparinux diberikan secara subkutan pada jam yang sama antara hari ke-3, 4, dan 5. Kemudian diperiksa nilai APTT dengan menggunakan alat Coatron M1, dan diperoleh hasil pemeriksaan nilai APTT pada masing-masing sampel penelitian.

\section{Instrumen}

Instrumen yang digunakan selama penelitian adalah rekam medis pasien dan hasil pengukuran nilai APTT. Data primer pasien diperoleh dari pemeriksaan laboratorium, meliputi terapi fondaparinux yang diberikan, termasuk tanggal pemberian, dosis, rute, dan lama pemberian; tanggal pengambilan sampel dan hasilnya. Sedangkan data sekunder pasien diperoleh dari rekam medis meliputi data demografi pasien, yaitu nama, usia, berat badan; data karakteristik klinik pasien, yaitu waktu MRS, diagnosis masuk rumah sakit, komplikasi, penyakit penyerta lain pada pasien.

\section{Analisis data}

Data akan dianalisis dengan analisis statistik deskriptif untuk menggambarkan karakteristik umum pasien dan hasil pengukuran APPT pada hari ke 0, 3, 4, dan 5. Untuk uji beda akan dilakukan dengan One Way Anova atau Kruskal-Wallis test.

\section{HASIL DAN PEMBAHASAN}

Telah dilakukan penelitian Pengaruh Lama Pemberian fondaparinux Terhadap APTT Penderita sindroma koroner akut di RSUD Dr. Soetomo Surabaya di ruang ICCU dan Ruang Perawatan Jantung. Pada mulanya jumlah sampel yang diteliti direncanakan sebesar 30 sampel, berdasarkan Dalil Limit Pusat (Central Limit Theorem) beranggapan mempunyai sifat distribusi normal (Budiarto, 2001). Namun setelah dihitung lebih lanjut berdasarkan data dari buku register pasien yang masuk di ICCU RSUD Dr. Soetomo bulan Januari 2011 - Juli 2011, jumlah rata-rata pasien NSTEMI dan UA sebesar 9 pasien per bulan, sehingga dibutuhkan waktu 3 - 4 bulan untuk mendapatkan 30 pasien.

Dari penelitian yang dilakukan selama bulan Agustus 2011 - Desember 2011, diperoleh hasil jumlah pasien yang masuk dengan diagnosa SKA (NSTEMI dan UA) sebesar 43 pasien (Tabel 1). Jumlah tersebut terbagi menjadi 3 bagian, yakni ada pasien yang mendapatkan terapi antikoagulan berupa Enoxaparin sebesar 12 pasien dan fondaparinux sebesar 25 pasien, sedangkan sisanya 6 pasien tidak diberikan terapi enoxaparin maupun fondaparinux. Sebesar 25 pasien NSTEMI dan UA yang mendapat terapi fondaparinux yang dirawat di ICCU, setelah kondisi stabil dan dapat dipindahkan di ruangan perawatan, ada yang dirawat di ruang perawatan jantung RSUD Dr. Soetomo sebesar 13 pasien, ada pula yang dirawat di RS lain sebesar 12 pasien yang diekslusi dari penelitian. Sebanyak 3 pasien dari 13 pasien yang dirawat dieksklusi dari penelitian dikarenakan pasien mengalami perdarahan selama pemberian fondaparinux dan 1 pasien meninggal di ruang perawatan jantung, sehingga diperoleh 9 sampel yang diteliti, seperti tampak pada Tabel 1. 
Tabel 1. Jumlah pasien SKA (NSTEMI/UA) yang diteliti di ICCU RSUD Dr. Soetomo yang mendapat fondaparinux

\begin{tabular}{|c|c|c|c|c|c|c|c|c|}
\hline \multirow{2}{*}{ Bulan } & \multicolumn{3}{|c|}{ ICCU } & \multicolumn{2}{|c|}{ Post ICCU } & \multirow{2}{*}{ Perdarahan } & \multirow{2}{*}{ Meninggal } & \multirow[t]{2}{*}{$\sum 2$} \\
\hline & NSTEMI & UA & $\sum 1$ & IRNA & LAIN & & & \\
\hline $\begin{array}{l}\text { Agustus } \\
2011\end{array}$ & 1 & 2 & 3 & 1 & 2 & 0 & 0 & 1 \\
\hline $\begin{array}{c}\text { September } \\
2011\end{array}$ & 2 & 3 & 5 & 4 & 1 & 1 & 0 & 3 \\
\hline $\begin{array}{c}\text { Oktober } \\
2011\end{array}$ & 3 & 2 & 5 & 3 & 2 & 0 & 0 & 3 \\
\hline $\begin{array}{c}\text { November } \\
2011\end{array}$ & 2 & 3 & 5 & 2 & 3 & 0 & 1 & 1 \\
\hline $\begin{array}{c}\text { Desember } \\
2011\end{array}$ & 3 & 4 & 7 & 3 & 4 & 2 & 0 & 1 \\
\hline JUMLAH & 11 & 14 & 25 & 13 & 12 & 3 & 1 & 9 \\
\hline
\end{tabular}

Keterangan: NSTEMI: Non ST-wafe Elevation Myocardial Infarction; UA: Unstable Angina; $\boldsymbol{\Sigma} 1$ : Jumlah pasien SKA (NSTEMI dan UA); $\boldsymbol{\Sigma} 2$ : Jumlah pasien SKA yang mendapat terapi fondaparinux

Data demografi pasien SKA yang diteliti berdasarkan diagnosa, jenis kelamin, usia, status biaya, faktor resiko, jumlah platelet, serum kreatinin, dan klirens kreatinin, dapat dilihat pada Tabel 2 yang menunjukkan bahwa nilai platelet harus lebih dari $100.000 / \mu \mathrm{L}$ untuk menurunkan resiko terjadi thrombositopenia, sehingga seluruh pasien dalam penelitian ini memiliki nilai platelet lebih dari $100.000 / \mu \mathrm{L}(100 \%)$. Dilihat dari nilai serum kreatinin, sebanyak $77,78 \%$ yang berada dalam rentang normal, sedangkan sisanya sebesar $22,22 \%$ memiliki nilai serum kreatinin diatas normal, yakni $>1,2 \mathrm{mg} / \mathrm{dL}$. Namun yang perlu dipertimbangkan dalam pemberian fondaparinux adalah nilai klirens kreatinin harus $>30$ $\mathrm{mL} / \mathrm{men}$. Dipengaruhi oleh usia dan berat badan yang berbeda, sembilan pasien yang diteliti memiliki nilai klirens kreatinin $>30 \mathrm{~mL} / \mathrm{men}$.

Sebanyak $22,22 \%$ sampel memiliki riwayat penyakit diabetes melitus, sedangkan $11,11 \%$ dengan riwayat penyakit diabetes melitus dan dislipidemia seperti yang tercantum pada Tabel 2. Pasien dengan diabetes melitus memiliki risiko tinggi mengalami kejadian atherothrombosis. Banyak penelitian telah menunjukkan bahwa diabetes melitus terkait kelainan hemostasis dan trombosis (Clement dkk., 2004; Lemkes dkk., 2010). Trombosis vena juga ditemukan terjadi lebih sering pada penderita diabetes. Delapan puluh persen pasien dengan diabetes melitus meninggal karena trombosis, dan $75 \%$ dari kematian ini disebabkan komplikasi kardiovaskular. Endotelium vaskular adalah bagian utama pertahanan terhadap trombosis dan abnormal pada pasien dengan diabetes melitus (Bick dkk., 1999).

Kadar Fibrinogen plasma mempengaruhi thrombogenesis, reologi darah, viskositas darah dan agregasi platelet. Studi epidemiologi telah menemukan hubungan yang signifikan antara kadar fibrinogen dan kadar insulin (Grant, 2007). Penanda fibrinolisis abnormal pada seseorang dengan sindrom metabolik dan disfungsi fibrinolitik meningkat tajam pada subyek dengan diabetes melitus dan obesitas perut (Anand dkk., 2003; Grant, 2007). Selain itu, hiperglikemia kronis dan glikasi jaringan memiliki efek pada struktur fibrin dan resistensi terhadap fibrinolisis (Grant, 2007). 
Tabel 2. Data demografi pasien SKA ( $n=9$ orang)

\begin{tabular}{llc}
\hline Parameter & & $\mathrm{n}(\%)$ \\
\hline Diagnosa & NSTEMI & 11,11 \\
& UA & 88,89 \\
\hline Jenis Kelamin & Laki-laki & 77,78 \\
& Perempuan & 22,22 \\
\hline Usia (tahun) & $40-49$ & 11,11 \\
& $50-59$ & 22,22 \\
& $60-69$ & 44,44 \\
& $>70$ & 22,22 \\
\hline Status Asuransi & Askes & 66,67 \\
& Jamkesmas & 22,22 \\
& Umum & 11,11 \\
\hline Faktor Resiko & Hipertensi & 33,34 \\
& Diabetes Melitus & 22,22 \\
& Hipertensi + Dislipidemia & 22,22 \\
& Diabetes Melitus + Dislipidemia & 11,11 \\
& Non Hipertensi + Diabetes Melitus + Dislipidemia & 11,11 \\
\hline Platelet $(/ \mu \mathrm{l})$ & $<100,000$ & 0 \\
& $>100,000$ & 100 \\
\hline SCr (mg/dL) & $0,5-1,2$ & 77,78 \\
& $>1,2$ & 22,22 \\
\hline ClCr (mL/men) & $<30$ & 0 \\
& $>30$ & 100
\end{tabular}

Keterangan: NSTEMI (Non ST-wafe Elevation Myocardial Infarction); UA (Unstable Angina); $\mathrm{SCr}$ (Serum Creatinin); $\mathrm{ClCr}$ (Clearence Creatinin)

Pemendekan APTT dapat mencerminkan ketidakseimbangan prokoagulan dengan peningkatan kadar faktor koagulasi. Oleh karena itu, APTT dapat digunakan untuk menilai risiko komplikasi tromboemboli pada pasien dengan diabetes melitus (Tripodi dkk., 2004; Lippi dkk., 2009). Nilai target APTT adalah 1,5 - 2,5 kali nilai normal. RSUD Dr. Soetomo menetapkan nilai normal APTT yakni sebesar 25 - 40 detik, sehingga nilai target APTT pada penelitian ini adalah 37,5 - 100 detik. Dari Tabel 3 diketahui hasil pemeriksaan APTT diperoleh hasil bahwa pemanjangan nilai APTT setelah pemberian fondaparinux selama 3 hari terjadi pada 5 orang pasien dari jumlah total 9 orang pasien, 4 orang pasien mengalami pemanjangan nilai APTT setelah pemberian fondaparinux selama 4 hari, dan 6 orang pasien mengalami pemanjangan nilai APTT setelah pemberian fondaparinux selama 5 hari. Tabel 3 juga menunjukkan bahwa nilai awal APTT rata-rata pasien yang diteliti adalah 35,29 detik. Pemberian fondaparinux dapat meningkatkan nilai APTT pada hari ke-3, terjadi peningkatan menjadi 39,39 detik atau meningkat sebesar 1,58 kali nilai APTT normal. Pada hari ke-4 juga terjadi peningkatan menjadi 39,98 detik atau meningkat sebesar 1,60 kali nilai APTT normal. Selanjutnya peningkatan nilai APTT pada hari ke-5 sebesar 40,06 detik atau meningkat sebesar 1,60 kali nilai APTT normal. Peningkatan APTT setelah pemberian fondaparinux hari ke-3, 4, dan 5 yang mencapai target 1,5 - 2,5 kali nilai normal APTT berdasarkan standar di RSUD Dr. Soetomo Surabaya. 
Tabel 3. Perkembangan nilai APTT selama pasien mendapat terapi fondaparinux

\begin{tabular}{cccccccccccc}
\hline $\begin{array}{c}\text { Nomor } \\
\text { Pasien }\end{array}$ & 1 & 2 & 3 & 4 & 5 & 6 & 7 & 8 & 9 & Rata-rata & $\begin{array}{c}\text { Nilai } \\
\text { Peningkatan }\end{array}$ \\
\hline Awal & 25,8 & $\mathbf{3 8 , 4}$ & $\mathbf{3 7 , 6}$ & 36 & 28,5 & $\mathbf{4 7 , 7}$ & 37 & 34,5 & 32,1 & $35,29 \pm 6,32$ & $1,41 \pm 0,25$ \\
Hari 3 & $\mathbf{3 7 , 8}$ & $\mathbf{4 3 , 7}$ & 30,8 & 32,4 & $\mathbf{5 7 , 1}$ & 36,3 & $\mathbf{4 2 , 5}$ & $\mathbf{4 0 , 6}$ & 33,3 & $39,39 \pm 8,02$ & $1,58 \pm 0,32$ \\
Hari 4 & 36,9 & 28,5 & 31,8 & 25,6 & $\mathbf{4 3 , 2}$ & $\mathbf{5 7 , 4}$ & $\mathbf{4 5 , 1}$ & $\mathbf{5 9 , 1}$ & 32,2 & $39,98 \pm 12,15$ & $1,60 \pm 0,49$ \\
Hari 5 & $\mathbf{3 9 , 9}$ & 31,7 & $\mathbf{3 8 , 6}$ & 33,6 & $\mathbf{5 0 , 6}$ & $\mathbf{4 3 , 8}$ & $\mathbf{3 9}$ & $\mathbf{4 7 , 3}$ & 36 & $40,06 \pm 6,21$ & $1,60 \pm 0,25$ \\
\hline
\end{tabular}

Keterangan: nilai APTT pasien > 37,5 (1,5 x APTT normal 25)

Pemeriksaan APTT dapat dilakukan dengan cara manual (visual) atau dengan alat otomatis (koagulometer), yang menggunakan metode foto-optik dan elektro-mekanik. Teknik manual memiliki bias individu yang sangat besar sehingga tidak dianjurkan lagi. Tetapi pada keadaan dimana kadar fibrinogen sangat rendah dan tidak dapat dideteksi dengan alat otomatis, metode ini masih dapat digunakan. Metode otomatis dapat memeriksa sampel dalam jumlah besar dengan cepat dan teliti.

Prinsip dari uji APTT adalah menginkubasikan plasma sitrat yang mengandung semua faktor koagulasi intrinsik kecuali kalsium dan trombosit dengan tromboplastin parsial (fosfolipid) dengan bahan pengaktif (misalnya, kaolin, ellagic acid, mikronized silica atau celite koloidal). Setelah ditambah kalsium maka akan terjadi bekuan fibrin. Waktu koagulasi dicatat sebagai APTT.

Bahan pemeriksaan yang digunakan adalah darah vena dengan antikoagulan trisodium sitrat $3,2 \%$ $(0,109 \mathrm{M})$ dengan perbandingan 9:1. Digunakan tabung plastik atau gelas yang dilapisi silikon. Sampel dicentrifuge selama 15 menit dengan kecepatan 2.500 rpm. Plasma dipisahkan dalam tabung plastik dalam waktu 4 jam pada suhu $20 \pm 5^{\circ} \mathrm{C}$. Jika dalam terapi heparin, plasma masih stabil dalam waktu 2 jam pada suhu $20 \pm 5^{\circ} \mathrm{C}$ kalau sampling dengan antikoagulan citrate dan 4 jam pada suhu $20 \pm 5^{\circ} \mathrm{C}$ kalau sampling dengan tabung CTAD (Citrate, Theophylline, Adenosine and Dipyridamole).

Nilai normal uji APTT di RSUD Dr. Soetomo adalah 25 - 40 detik. Faktor yang dapat mempengaruhi temuan laboratorium diantaranya adalah pembekuan sampel darah, sampel darah hemolisis atau berbusa akibat dikocok-kocok, pengambilan sampel darah pada intravena-lines (misal pada infus heparin).

Hasil pemeriksaan nilai APTT pada masingmasing sampel penelitian seperti ditampilkan pada Tabel 3. Nilai target APTT adalah 1,5 - 2,5 kali nilai normal. RSUD Dr. Soetomo menetapkan nilai normal APTT yakni sebesar 25 - 40 detik, sehingga nilai target APTT pada penelitian ini adalah 37,5 - 100 detik. Dari
Tabel 3 diketahui hasil pemeriksaan APTT diperoleh hasil bahwa pemanjangan nilai APTT setelah pemberian fondaparinux selama 3 hari terjadi pada 5 orang pasien dari jumlah total 9 orang pasien, 4 orang pasien mengalami pemanjangan nilai APTT setelah pemberian fondaparinux selama 4 hari, dan 6 orang pasien mengalami pemanjangan nilai APTT setelah pemberian fondaparinux selama 5 hari.

Rata-rata peningkatan nilai APTT awal, hari ke-3, 4, dan 5 dapat dilihat pada Tabel 3 yang menunjukkan bahwa nilai awal APTT rata-rata pasien yang diteliti adalah 35,29 detik. Pemberian fondaparinux dapat meningkatkan nilai APTT pada hari ke-3, terjadi peningkatan menjadi 39,39 detik atau meningkat sebesar 1,58 kali nilai APTT normal. Pada hari ke-4 juga terjadi peningkatan menjadi 39,98 detik atau meningkat sebesar 1,60 kali nilai APTT normal. Selanjutnya peningkatan nilai APTT pada hari ke-5 sebesar 40,06 detik atau meningkat sebesar 1,60 kali nilai APTT normal. Peningkatan nilai APTT dalam penelitian ini tidak melebihi ambang atas yaitu 2,5 kali nilai APTT normal, yakni sebesar 100 detik. Diduga bahwa peningkatan nilai APTT diatas nilai tersebut dapat terjadi perdarahan. Perdarahan yang umum terjadi adalah hematuri dan hemoptoe. Dua dari sampel yang diekslusi mengalami hematuri, sedangkan satu sampel mengalami hemoptoe. Ketiga penderita tersebut diekslusi, sehingga tidak dilakukan pengukuran nilai APTT selanjutnya.

Pada bulan Oktober 2008, FDA (Food and Drud Associations) merevisi labeling keamanan untuk injeksi $\mathrm{Na}$ fondaparinux (Arixtra, GlaxoSmithKline) dengan membuat peringatan peningkatan potensial APTT terkait dengan kejadian perdarahan. Hal ini dilaporkan terjadi setelah pemberian injeksi $\mathrm{Na}$ fondaparinux dengan atau tanpa pemberian antikoagulan lain. Pengalaman pasca pemasaran termasuk laporan kejadian peningkatan APTT setelah pemberian injeksi $\mathrm{Na}$ fondaparinux, seperti halnya kejadian trombositopenia dengan trombosis yang menyerupai trombositopenia yang diinduksi heparin dan beberapa kasus hematoma epidural atau spinal. Oleh karena itu 
APTT sebaiknya digunakan sebagai pemeriksaan rutin penderita yang mendapatkan pengobatan fondaparinux (Barclay, 2009).

Penelitian ini memiliki kelemahan yaitu waktu penelitian yang terbatas hanya 5 bulan sangat berpengaruh terhadap jumlah sampel yang diperoleh, mengingat jumlah rata-rata pasien yang masuk dengan diagnosa NSTEMI/UA yang mendapat fondaparinux adalah 5 pasien per bulan. Untuk itu perlu dilakukan penelitian lebih lanjut dengan memperpanjang waktu penelitian agar diperoleh jumlah sampel yang cukup sehingga hasil penelitian dapat lebih dioptimalkan. Pada penelitian ini tidak dilakukan evaluasi pemeriksaan APTT lebih lanjut pada pasien yang dieksklusi karena terjadi perdarahan. Sebaiknya tetap dilakukan pemeriksaan APTT untuk mengetahui nilai batas APTT yang menyebabkan perdarahan, apakah ada peningkatan nilai APTT lebih dari 1,5 - 2,5 kali nilai APTT normal sebesar 25 - 40 detik.

Penelitian ini menunjukkan bahwa penggunaan fondaparinux dapat meningkatkan APTT dengan ratarata nilai APTT telah mencapai target sebesar 1,5 - 2,5 kali dari nilai APTT normal 25 - 40 detik yakni 37,5 detik selama 3 hari $(39,39 \pm 8,02$ detik), 4 hari $(39,98 \pm$ 12,15 detik), dan 5 hari $(40,06 \pm 6,21$ detik). Sebelum dilakukan uji beda, dilakukan uji normality data. Shapiro-Wilk test menunjukkan bahwa data memiliki distribusi tidak normal ( $\mathrm{p}=0,046)$. Dari hasil uji beda menggunakan Kruskal-Wallis test menunjukkan tidak ada perbedaan signifikan antara nilai APTT awal, 3 hari, 4 hari dan 5 hari $(\mathrm{p}=0,548)$. Hasil dari penelitian ini belum dapat digeneralisasikan, hal ini dikarenakan jumlah sampel yang terlalu kecil, untuk itu diperlukan penelitian lebih lanjut dengan jumlah sampel yang lebih besar.

\section{KESIMPULAN}

Lama pemberian fondaparinux pada hari ke-3, 4, dan 5 tidak berbeda bermakna dalam meningkatkan nilai APTT pasien SKA.

Diperlukan penelitian lebih lanjut dalam jangka waktu yang lebih lama sehingga diperoleh jumlah sampel yang lebih besar. Pemeriksaan nilai APTT seharusnya tetap dilakukan pada penderita yang diekslusi karena perdarahan agar dapat diketahui nilai batas atas APTT yang menyebabkan perdarahan. Pemeriksaan APTT dapat digunakan sebagai pemeriksaan rutin pada penderita yang mendapatkan fondaparinux.

\section{UCAPAN TERIMA KASIH}

Peneliti menyampaikan terima kasih kepada Dokter, perawat, serta pasien di ICCU dan Ruang Rawat Inap Jantung RSUD Dr. Soetomo sehingga penelitian ini dapat berlangsung dengan baik.

\section{DAFTAR PUSTAKA}

Anand, S. S., Yi, Q., Gerstein, H., Lonn, E., Jacobs, R.,Vuksan, V., Teo, K., Davis, B., Montague, P. \& Yusuf S. (2003). Relationship of Metabolic Syndrome and Fibrinolytic Dysfunction to Cardiovascular Disease. Circulation; 108; 420 425.

Anderson, J. L., Adams, C. D., Antman, E. M., Bridges, C. R., Califf, R. M., Casey, D. E., Chavey, W. E., Fesmire, F. M., Hochman, J. S., Levin, T. N., Lincoff, A. M., Peterson, E. D., Theroux, P., Wenger, N. K., Wright, R. S., Smith, S. C. Jacobs, A. K., Halperin, J. L., Hunt, S. A., Krumholz, H. M., Kushner, F. G., Lytle, B. W., Nishimura, R., Ornato, J. P., Page, R. L. \& Riegel, B. (2007). ACC/AHA 2007 Guidelines for the Management of Patients with Unstable Angina/Non ST-Elevation Myocardial Infarction: A Report of the American College of Cardiology/American Heart Association Task Force on Practice Guidelines (Writing Committee to Revise the 2002 Guidelines for the Management of Patients With Unstable Angina/Non ST-Elevation Myocardial Infarction): Developed in Collaboration with the American College of Emergency Physicians, the Society for Cardiovascular Angiography and Interventions, and the Society of Thoracic Surgeons: Endorsed by the American Association of Cardiovascular and Pulmonary Rehabilitation and the Society for Academic Emergency Medicine. Circulation; 116; e148e304.

Bassand, J. P. (2007). Guideline for the Diagnosis and Treatment of Non-ST- Segment Elevation Acute Coronary Syndromes. Europen Society of Cardiology; 28; 1598-1660.

Bick, R.L., Arun, B. \& Frenkel, E. P. (1999). Disseminated Intravascular Coagulation, Clinical and Pathophysiological Mechanisms and Manifestations. Haemostasis; 29; 111-134.

Budiarto, E. (2001). Biostatistika untuk Kedokteran dan Kesehatan Masyarakat. Jakarta: EGC. 
Clement, S., Braithwaite, S. S., Magee, M. F., Ahmann, A., Smith, E. P., Schafer, R. G. \& Hirsch, I. B. (2004). American Diabetes Association Diabetes in Hospitals Writing Committee Management of Diabetes and Hyperglycemia in Hospitals. Diabetes Care; 27; 553-591.

Grant, P. J. (2007). Diabetes Melitus as a Prothrombotic Condition. Journal of Internal Medicine; 262; 157-172.

Barclay, L. (2009). FDA Safety Changes: Prevacid NapraPAC 500, Prezista, Fondaparinux Sodium (Arixtra) Injection Linked to Elevated aPTT With Bleeding Events by Medscape. http://www.medscape.com/viewarticle/ 587156. Accessed: 23 Februari 2012.

Lemkes, B. A., Hermanides, J., Devries, J. H., Holleman, F., Meijers, J. C. \& Hoekstra, J. B. (2010). Hyperglycemia, A Prothrombotic Factor?. Journal of Thrombosis and Haemostasis; 8; 1663-1669.

Lippi, G., Franchini, M., Targher, G., Montagnana, M., Salvagno, G. L., Guidi, G. C. \& Favaloro, E. J. (2009). Epidemiological Association between
Fasting Plasma Glucose and Shortened APTT. Clinical Biochemistry; 42; 118-120.

Organon Sanofi-Synthelabo. (2002). Product Information: Arixtra ${ }^{\circledR}$, Fondaparinux. West Orange: Organon Sanofi-Synthelabo LLC.

Simoons, M. L., Bobbink, I. W., Boland, J., Gardien, M., Klootwijk, P., Lensing, A. W., Ruzyllo, W., Umans, V. A., Vahanian, A., Werf, V. D. F. \& Zeymer, U. (2004). A Dose-Finding Study of Fondaparinux in Patients With Non-STSegment Elevation Acute Coronary Syndromes. Journal of the American College of Cardiology; 43; 2183-2190.

Smogorzewska, A., Brandt, J. T., Chandler, W. L., Cunningham, M. T., Hayes, T. E., Olson, J. D., Kottke-Marchant, K., \& Van Cott, E. M. (2006). Effect of Fondaparinux on Coagulation Assays: Results of College of American Pathologists proficiency Testing. Archives of Pathology \& Laboratory Medicine; 130; 1605-1611.

Tripodi, A., Chantarangkul, V., Martinelli, I., Bucciarelli, P. \& Mannucci, P. M. (2004). A Shortened Activated Partial Thromboplastin Time is Associated with the Risk of Venous Thromboembolism. Blood; 104; 3631-3634. 